\title{
Evaluation of spring and autumn applied insecticides for the control of black beetle
}

\author{
T.M. Eden ${ }^{1}$, P.J. Gerard ${ }^{1}$, D.J. Wilson ${ }^{1}$ and P.J. Addison ${ }^{2}$ \\ ${ }^{1}$ AgResearch, Ruakura Research Centre, Private Bag 3123, Hamilton, New Zealand \\ ${ }^{2}$ Nufarm, PO Box 22407, Auckland 1640, New Zealand \\ Corresponding author: tina.eden@agresearch.co.nz
}

\begin{abstract}
Black beetle (Heteronychus arator) is a sporadic but serious pest of North Island pastures. Field trials were established to test the efficacy of insecticides currently registered for use against scarab pests in pasture. Three life stages were targeted: newly emerged black beetle adults in autumn, egg-laying adults in spring and newly hatched larvae in early summer. Although the insecticides used caused significant beetle mortalities in spring, no treatment reduced the subsequent larval populations in summer. Similarly, while the autumn application caused significant beetle mortality; the number of surviving black beetle adults remaining in the plots was not affected. Soil factors and the high mobility of adult beetles are likely to have contributed to treatment failure.
\end{abstract}

Keywords black beetle, Heteronychus arator, insecticide, pasture.

\section{INTRODUCTION}

Although sporadic, black beetle (Heteronychus arator (F.)(Scarabaeidae)) is a major problem in northern North Island pastures. Severe pasture damage was documented in 1957-59, 1961-63, 1968, 1970-75 (King 1979), 1999-2000 (Watson et al. 2000) and more recently from 2007 (Bell et al. 2011). These outbreaks have all coincided with La Niña weather patterns where warmer conditions than normal occur (NIWA 2011). Warm springs allow for early oviposition, rapid egg and larval development, and greater survival over summer (East et al. 1981). Ryegrass pastures are vulnerable to black beetle damage, especially if paspalum (King 1976) or a susceptible endophyte is present (Popay \& Thom 2009). Larval feeding during summer often results in plant pulling by stock (Watson et al. 2000), and in severe cases the pasture composition changes as the bare ground is taken over by clover and weeds (Todd 1964).

Chemicals have been applied to pastures in an attempt to reduce black beetle populations since the 1950s. However, insecticides such as dieldrin, which gave good control of black beetle, have long been banned from use (King \& Mercer 1974). Chlopyrifos, alpha-cypermethrin and diazinon have current registration for activity against scarabs, but field testing against black beetle over the last 40 years has resulted in inconsistent levels of control. Although no insecticides are currently recommended for use against black beetle in pasture, many farmers are resorting to them in the hope that they will give adequate control.

This paper presents results from two field trials where three insecticides were used to target different stages of the black beetle life cycle. 


\section{METHODS}

\section{Autumn application against adults}

The trials were conducted on two farms in the Waikato (Gordonton and Ruawaro) in April 2001. Initial black beetle populations were determined by counting the beetles in 25 spade-squares $(200 \mathrm{~mm} \times 200 \mathrm{~mm})$ within the trial area. Insecticides used were alpha-cypermethrin (Fastac ${ }^{\circledR}, 10$ and $15 \mathrm{~g}$ ai/ha) and chlorpyrifos (Lorsban ${ }^{\circledR}, 60 \mathrm{~g}$ ai/ha) (Table 1). Treatments were applied during the first week of April 2001 using a $\mathrm{CO}_{2}$ powered precision sprayer with a $3 \mathrm{~m}$ wide hand-held boom fitted with Tee Jet 80015 nozzles and operated at $200 \mathrm{kPa}$. Application volume was 150 litres/ha. Plot size at each farm was $15 \mathrm{~m} \times$ $15 \mathrm{~m}$ and each treatment was replicated four times in a randomised block design. Pasture at the Gordonton site was grazed just before application, whereas the Ruawaro site was new pasture and treatments were applied 4 weeks after sowing.

Three days after treatment application, dead black beetles on the soil surface were counted in 10 randomly placed quadrats $(645 \mathrm{~mm} \times$ $345 \mathrm{~mm}$ ) per plot at the Gordonton site only. Ten days after treatment, 15 spade-squares $(200 \mathrm{~mm}$ $\times 200 \mathrm{~mm}$ ) per plot were hand-sorted at both sites, and live and dead (included moribund) beetles recorded per sample.

\section{Spring application against adults}

The trials were established on three farms in the Waikato, (Gordonton, Morrinsville and Ruakura) in October 2010. The Gordonton and Morrinsville sites had peat soil whereas the Ruakura site had a mineral soil high in organic matter. Pre-treatment black beetle populations were determined at each farm by counting the number of beetles in 40 spade-squares over each trial area. Insecticides used were alphacypermethrin (Fastac ${ }^{\circledR}, 15 \mathrm{~g}$ ai/ha), chlorpyrifos (Chlorpyrifos $48 \mathrm{EC}, 72 \mathrm{~g}$ ai/ha) and diazinon (Diazinon 20G, $2200 \mathrm{~g}$ ai/ha) (Table 2). All treatments were applied 2 days after grazing between 7 and 19 October. Chlorpyrifos and alpha-cypermethrin were applied using a $\mathrm{CO}_{2}$ powered precision sprayer, whereas diazinon was measured into containers and broadcast over the plots by hand through a perforated lid. For all trials, plot size was $12 \mathrm{~m} \times 12 \mathrm{~m}$ with four replicates per treatment in a randomised block. Treatments were applied in dry conditions and rainfall occurred prior to and 2 days following treatment. Seven days post-treatment, five spade squares per plot were hand-sorted and the number of beetles found alive or dead was recorded per sample.

Because black beetle adult populations are low in spring, an additional experiment (ring trial) was conducted at the Ruakura trial site. At $24 \mathrm{~h}$ after insecticide treatment, six $30 \mathrm{~cm}$ diameter rings were hammered into the soil in each of the untreated, alpha-cypermethrin and chlorpyrifos treated plots. No dead beetles were observed on the surface at the time. Five adult beetles were then seeded into each ring. Dead beetles on the soil surface were counted and removed at 1, 2, 4 and 6 days after being introduced. The soil inside the rings was dug up 10 days after treatment and all beetles found were recorded.

The effect of the treatments on the subsequent larval generation was determined by counting the number of larvae present in ten $10 \mathrm{~cm}$ diameter cores/plot between 12 and 17 January 2011. An additional 15 cores/plot were assessed on 2 February 2011 at each trial site in the chlorpyrifos and alpha-cypermethrin treated plots only.

\section{Summer application against larvae}

This summer application was part of the above 2010 randomised block trial. However, treatment of plots with diazinon was delayed until 20 December 2010 when newly hatched larvae were present and sufficient rainfall had occurred to allow movement of the pesticide into the soil. Rainfall occurred just prior to application (16 mm) and over the following 2 days $(80 \mathrm{~mm})$. Plots were sampled once in mid January, being 4 weeks post treatment and coinciding with the sampling of the spring-treated plots.

All data were analysed using ANOVA in GenStat.

\section{RESULTS}

\section{Autumn application against adults}

Pre-treatment black beetle populations at the 
Gordonton and Ruawaro sites were 27 and $38 / \mathrm{m}^{2}$, respectively. At the Gordonton site 3 days post-treatment, more dead adults were found on the soil surface in the alpha-cypermethrin-treated plots than in the chlorpyrifos or untreated plots $(\mathrm{P}<0.001)$ (Table 1). There were also significantly higher numbers of dead adults found in the soil samples from both alpha-cypermethrin treatment rates compared to the untreated plots $(\mathrm{P}<0.01)$ (Table 1). However, at the Ruawaro site, alphacypermethrin caused significant beetle mortality at the $15 \mathrm{~g}$ ai/ha rate only $(\mathrm{P}<0.05)$. Chlorpyrifos had little effect on the number of live or dead beetles at either site. No treatment significantly reduced the number of live beetles recovered with similar numbers found in all plots.

\section{Spring application against adults}

Pre-treatment sampling at the Gordonton, Morrinsville and Ruakura sites revealed black beetle spring populations of $10 / \mathrm{m}^{2}, 18 / \mathrm{m}^{2}$ and $9 / \mathrm{m}^{2}$ respectively. Post-treatment results between the three farms were not significantly different, so the pooled data are presented (Table 2). There was no difference in the number of live adults found in the spade squares 1 week post treatment and there were too few dead adults recovered to analyse. However, when beetles were seeded into the ring trial, the percentage of dead beetles recovered after 10 days was significantly higher in the chlorpyrifos and alpha-cypermethrin-treated rings compared with untreated $(\mathrm{P}<0.05)$.

There was no significant difference in larval numbers in the treated plots compared with untreated plots when sampled in January 2011 (Table 2). As the additional larval assessment in February made little difference to the analyses, only the January data are presented.

\section{Summer application against larvae}

Pre-sampling of the plots at 1 week prior to treatment showed the larval population was only $11 / \mathrm{m}^{2}$. However, black beetle eggs were also present at this time (data not presented). The December application of diazinon granules resulted in no significant reduction in larval numbers at 4 weeks post treatment compared with untreated plots (Table 2).

\section{DISCUSSION}

Although alpha-cypermethrin and chlorpyrifos at the rates evaluated killed black beetle adults, they had no impact on live beetles remaining after treatment. After the spring application, subsequent larval populations were $50 / \mathrm{m}^{2}$ and $41 / \mathrm{m}^{2}$ respectively. A larval population of $40 / \mathrm{m}^{2}$ has been known to cause considerable damage to ryegrass pastures (King \& East 1979), while

Table 1 Black beetle adults (number $/ \mathrm{m}^{2}$ ) found dead on the soil surface at 3 days and alive or dead at 10 days in spade squares in insecticide-treated pasture in autumn.

\begin{tabular}{|c|c|c|c|c|c|}
\hline \multirow[b]{2}{*}{ Trial site } & \multirow[b]{2}{*}{ Treatment } & \multirow{2}{*}{$\begin{array}{c}\text { Rate } \\
\text { (g ai/ha) }\end{array}$} & \multirow{2}{*}{$\frac{\text { Soil surface }}{\text { dead }}$} & \multicolumn{2}{|c|}{ Spade squares } \\
\hline & & & & live & dead \\
\hline \multirow[t]{5}{*}{ Gordonton } & Untreated & & 0.1 & 15.9 & 0.4 \\
\hline & alpha-cypermethrin & 10 & $4.9^{\star * *}$ & 23.4 & $8.0^{\star *}$ \\
\hline & alpha-cypermethrin & 15 & $6.9^{* * *}$ & 18.4 & $7.5^{\star *}$ \\
\hline & chlorpyrifos & 60 & 0.2 & 16.3 & 3.3 \\
\hline & $\operatorname{LSD}(\mathrm{P}<0.05)$ & & 2.1 & 7.9 & 4.8 \\
\hline \multirow[t]{5}{*}{ Ruawaro } & Untreated & & - & 29.6 & 0.4 \\
\hline & alpha-cypermethrin & 10 & - & 33.8 & 1.3 \\
\hline & alpha-cypermethrin & 15 & - & 31.3 & $7.1^{\star}$ \\
\hline & chlorpyrifos & 60 & - & 26.3 & 1.7 \\
\hline & LSD $(\mathrm{P}<0.05)$ & & - & 9.7 & 6.0 \\
\hline
\end{tabular}

Asterisks indicate treatments significantly different to the untreated control $\left({ }^{* *} \mathrm{P}<0.001,{ }^{* * \mathrm{P}<0.01}\right.$, ${ }^{\star} \mathrm{P}<0.05$ ). 
Table 2 Mortality (\%) of adults seeded into the Ruakura ring trial 10 days after insecticide treatment, live adults $/ \mathrm{m}^{2}$ recovered 1 week post spring application and resulting larval populations in January 2011 (Gordonton, Morrinsville and Ruakura plot data combined).

\begin{tabular}{lcccc}
\hline Treatment and application timing & $\begin{array}{c}\text { Rate } \\
\text { (g ai/ha) }\end{array}$ & $\begin{array}{c}\text { \% mortality in } \\
\text { ring trial }\end{array}$ & $\begin{array}{c}\text { Live adults/ } \\
\mathrm{m}^{2}\end{array}$ & $\begin{array}{c}\text { Live larvae/ } \\
\mathrm{m}^{2}\end{array}$ \\
\hline Untreated & - & 0 & 8.3 & 64 \\
alpha-cypermethrin (spring) & 15 & $30^{*}$ & 8.3 & 50 \\
chlorpyrifos (spring) & 72 & $40^{*}$ & 7.9 & 41 \\
Diazinon (spring) & 2200 & - & 5.4 & 67 \\
Diazinon (summer) & 2200 & - & - & 61 \\
\hline LSD (P<0.05) & & 28 & 6.2 & 24 \\
\hline
\end{tabular}

* indicates treatments significantly different to the untreated control $(\mathrm{P}<0.05)$.

$15-20 / \mathrm{m}^{2}$ can cause severe ryegrass plant mortality during drought conditions (P.J. Addison, personal observations). Similar results where insecticides have been ineffective in controlling black beetle have been reported previously. In a field scale trial, chlorpyrifos gave poor control of larvae when applied at $2 \mathrm{~kg} / \mathrm{ha}$ in December (Watson \& Wren 1980) as did diazinon (Watson et al. 1978; Blank et al. 1982). However, applications have been effective when test sites had sandy loam soil: Todd (1969) found a broadcast application of diazinon in either autumn or spring resulted in over $80 \%$ adult mortalities when beetles were seeded and confined on plots and Watson \& Webber (1976) achieved a significant reduction in larval numbers after a December treatment of diazinon. In all trials diazinon had been applied at either 2 or $2.2 \mathrm{~kg} / \mathrm{ha}$ as in the current trial.

Black beetle populations and damage is usually greatest on coastal sands and soils with high organic matter content (Blank \& Olsen 1988). Previous studies have indicated that organic matter plays a major role in the inactivation of insecticides in soil (King \& Mercer 1974; Watson \& Webber 1975), which largely explains the lack of effect in past and current trials. All three sites in the 2010/11 trial had soil high in organic matter. Application timing is also important, especially that of diazinon in its granular formulation, which requires rainfall or high soil moisture in order to penetrate the soil (Udy 1977). Also, if diazinon is applied too early in summer when few eggs have hatched, the targeted larvae could be missed.
Chemicals such as diazinon that have short residual activity may therefore only be effective if applied once egg laying is complete (Watson et al. 1978). This may have occurred in the current study as the larval population was only $11 / \mathrm{m}^{2}$ in the pretreatment sampling and increased to $>60 / \mathrm{m}^{2}$ in January. In addition, there is difficulty in achieving good exposure of the pest to the insecticide. As the insecticides tested are not systemic and the larvae feed below the soil surface, they may ingest no insecticide. Although the beetles feed on the base of stems, they are often found below the soil surface so may also contact little, if any, insecticide. The beetles are also very mobile with mass flights often occurring in autumn (King 1979) allowing for infestation into new areas. Both flight and ground dispersal would have contributed to the lack of efficacy of the insecticidal treatments against adults in the plot experiments, in spite of dead beetles being observed on the soil surface.

Because of the difficulty in application timing, the inefficacy of treatments on the black beetleprone peaty soils, the likelihood of beetle reinvasion and that it will not prevent subsequent damaging larval populations, the use of the pesticides reported in this paper to control black beetle in pasture is not recommended. However, previous work has shown that establishing a non-host crop prior to pasture renewal to reduce black beetle populations (Bell et al. 2011) and then sowing seed containing an endophyte with proven black beetle deterrence (Popay \& Thom 2009) to be beneficial in black beetle prone areas. 


\section{ACKNOWLEDGEMENTS}

The authors acknowledge and thank Nigel Bell, Claire Dowsett, Marie Vasse and Yasmine Lovell for their help in establishing and assessing these trials. The 2010 work was funded by DairyNZ (Objective FD606) and the 2001 trial by BASF.

\section{REFERENCES}

Bell NL, Townsend RJ, Popay AJ, Mercer CF, Jackson TA 2011. Black beetle: lessons from the past and options for the future. New Zealand Grassland Association Pasture Persistence Symposium. Grassland Research and Practice Series 15: 119-124.

Blank RH, Olsen MH, Bell DS 1982. Insecticidal control of black beetle (Heteronychus arator) in pasture. New Zealand Journal of Experimental Agriculture 10: 433-438.

Blank RH, Olsen MH 1988. Effect of black beetle, in association with nitrogen and summer spelling, on pasture production on sandy soils. New Zealand Journal of Agricultural Research 31: 445-453.

East R, King PD, Watson RN 1981. Population studies of grass grub (Costelytra zealandica) and black beetle (Heteronychus arator) (Coleoptera: Scarabaeidae). New Zealand Journal of Ecology 4: 56-64.

King PD, Mercer CF, Meekings JF 1974. Insecticidal control of black beetle on a peat soil type. Proceedings of the $27^{\text {th }}$ New Zealand Weed and Pest Control Conference: 228-229.

King PD 1976. Effect of pasture species on black beetle. Proceedings of the $29^{\text {th }}$ New Zealand Weed and Pest Control Conference: 161-164.

King PD 1979. Aspects of the ecology of black beetle (Heteronychus arator (F.), Coleoptera: Dynastinae). Unpublished D. Phil. Thesis, University of Waikato, New Zealand.

King PD, East R 1979. Effects of pasture composition on the dynamics of Heteronychus arator and Graphognathus leucoloma populations (Coleoptera: Scarabaeidae and Curculionidae). Proceedings of the $2^{\text {nd }}$ Australasian Conference on Grassland Invertebrate Ecology: 79-82.
NIWA 2011 http://www.niwa.co.nz/our-science/ climate/information-and-resources/clivar/ elnino (accessed 21 April 2011).

Popay AJ, Thom ER 2009. Endophyte effects on major insect pests in Waikato dairy pasture. Proceedings of the New Zealand Grassland Association 71: 121-126.

Todd DH 1964. Biology and control of black beetle. Proceedings of the $17^{\text {th }}$ New Zealand Weed and Pest Control Conference: 119-124.

Todd DH 1969. Results of field experiments with diazinon and other transient chemicals for control of black beetle adults in pasture. Proceedings of the $22^{\text {nd }}$ New Zealand Weed and Pest Control Conference: 296-300.

Udy PB 1977. Factors influencing the release of insecticides from granular formulations and their subsequent diffusion into a range of New Zealand soils. New Zealand Journal of Agricultural Research 20: 79-85.

Watson RN, Webber KJ 1975. Effect of two soil types on insecticide activity against black beetle adults. Proceedings of the $28^{\text {th }} \mathrm{New}$ Zealand Weed and Pest Control Conference: 119-120.

Watson RN, Webber KJ 1976. Insecticide trials against black beetle in pasture. Proceedings of the $29^{\text {th }}$ New Zealand Weed and Pest Control Conference: 176-179.

Watson RN, Holland PT, Olson MH 1978. Residual activity of two insecticides against black beetle. Proceedings of the $31^{\text {st }} \mathrm{New}$ Zealand Weed and Pest Control Conference: 167-172.

Watson RN, Wrenn NR 1980. An evaluation of the solid stream technique of insecticide application for control of black beetle in pasture. Proceedings of the $33^{\text {rd }}$ New Zealand Weed and Pest Control Conference: 151-154.

Watson RN, Bell NL, Neville FJ, Davis LT 2000. Pest populations during the first six years in ryegrass pastures containing white or Caucasian clover. New Zealand Plant Protection 53: 410-414. 